\title{
Does Abortion Take A Human Life? Thomas Aquinas Answers
}

\author{
Nico P. Swartz ${ }^{1}$, Odirile Otto Itumeleng ${ }^{1}$, Rekha Kumar ${ }^{1}$, Refilwe Segokgo $^{1}$, Mr Wankie $^{1} \&$ Anisha Jeelabdeen ${ }^{1}$ \\ ${ }^{1}$ Department of Law, Faculty of Social Sciences, University of Botswana, Gaborone, Botswana \\ Correspondence: Nico P. Swartz, Department of Law, Faculty of Social Sciences, University of Botswana, \\ Gaborone, Botswana. Tel: 1-613-947-3592. E-mail: Nico.Swartz@mopipi.ub.bw
}

Received: October 8, 2012 Accepted: May 22, 2013 Online Published: July 19, 2013

doi:10.5539/res.v5n4p88 URL: http://dx.doi.org/10.5539/res.v5n4p88

--None of us was ever a fetus.

\begin{abstract}
The paper dwells on the research questions as to whether abortion takes a human life and when human life begins? Thomas Aquinas's answers on the question will be provided in this paper. But the research aims to interrogate his answers and will critically reflect on them. In doing so, the paper's methodology opted for an exploratory study using primary and secondary data on which the author draws. The data so required will enable the research to furnish an impressionistic account of the ideas produced by the works of Aquinas, Aristotle and Plato on the one hand, and the works of contemporary philosophers and writers on the other hand. In other words, this data is going to be complemented by documentary analysis and the author's critical insight, so as to warrant the article as to presenting new knowledge. The findings of this research will prove to have larger import beyond the specific case or instance under investigation. It reopens the issue of a revival of the implementation of the dignity of human life. The Church opposes every threat to human life from the moment of conception. The threat to human life is most intense at the point where life begins - at that stage where it is at its most defenseless. It is at this moment (pre-natal stage) when human beings are totally dependent on the goodwill and care of others. Humankind is obliged to respect life. It expresses the human persons's relationship to other persons: and it is valid from the first moment of conception through to adulthood. The fetus also is a fellow human being and his or her rights should be respected just as the case would with every other human being. These methodological observations present an innovative, thorough and systematic attempt to address the research questions mentioned above.
\end{abstract}

Keywords: abortion, evangelium vitae, ensoulment, zigot, oosperm, embriologists, ethicists, fetal development

\section{Introduction}

The Hippocratic Oath contains the following wording, "[...] I will not give to a woman an abortive remedy (Note 1)." Abortion was practiced in the Persian Empire, in Greek times as well as in the Roman Era. The Ephesian, Soranos appeared to have been generally opposed to Rome's prevailing free-abortion practices (Note 2). Greek and Roman law afforded little protection to the unborn. If abortion was prosecuted, it seems to have been based on a concept of a violation of the father's right to his offspring (Note 3). Although the Hippocratic Oath existed, abortion practices were still rife in Rome. The reason for this seems to be that the Oath was not uncontested even in Hippocrates' day (Note 4). Except for the Pythagorean School of philosophers, most Greek and Roman thinkers commended abortion (Note 5).

For the Pythagoreans the fetus was animate from the moment of conception and abortion meant destruction of a living being. It was a matter of dogma to them (Note 6). But this was a Pythagorean thesis and not the expression of an absolute standard of medical conduct (Note 7).

Under the influence of the Pythagorean School of thought, resistance against abortion became common. The emerging teachings of Christianity show a similar ethic to that of the Pythagorean teaching (Note 8).

\section{Thomas Aquinas's Position with Regard to Abortion vis-à-vis the Catholic Church}

It is unfortunate to identify interest in Medieval philosophy, especially in the work of Thomas Aquinas, with the Catholic Church's stand on abortion. Abortion and the right-to-life movement have become part of the defining character of Catholicism (Note 9). The Church's alternatives to have an awareness of a "culture of life" that will take hold in civil society. This impetus stirs the Church to oppose every threat to human life from the moment of 
conception. The Church's sentiment is that when God created the human soul, He clothed humans in godlikeness. Human life, therefore, has a sacred and inviolable quality. The Church urges people therefore to respect human life. The Church's outcry reverberated all over the world: "The fetus also is a fellow human being and his or her rights should be respected just as the case would be with every other human being" (Note 10).

Irrespective of these noble doctrines of the Church, it has never taken a position on the philosophical question of when human life begins. In the encyclical, Evangelium Vitae, Pope John Paul II noted that the Church has not "expressly committed itself" on the moment when human life begins (Note 11). But the Church's rhetoric leaves little room for doubt. In that same encyclical, the Pope wrote that abortion "destroys the life of a human being" and "directly violates the divine commandment 'You shall not kill" (Note 12). That seems fairly express.

The inertia of the Church concerning the issue of when human life begins, has engendered that one of its chief philosophers, Thomas Aquinas, push for a stand against the Church's "culture of life" phenomenon (Note 13). Thomas Aquinas did so regardless of the Church's disinclination to his writings. Thomas Aquinas assertion on when human life begins has founded its origin in the works of Aristotle (Note 14). With regard to the distinction between early and late beginning of life and Thomas Aquinas preference for the latter has caused him to collide with the Church. In respect of his differentiation, Thomas Aquinas meant that abortion can be executed during the early stage of pregnancy (early fetus). This is before human ensoulment (quickening), in other words, before the twentieth week of pregnancy. Only thereafter (late fetus), is abortion subject to criminalization and will it amounts to murder (Note 15). The Church consequently denounced Thomas Aquinas's notion on abortion, especially his permission that abortion is allowable during the early fetal stage. The Church therefore made an appeal in the encyclical, Congregation for the Doctrine of the Faith (1987) that the human being's dignity and rights to be protected at all times. These fundamental values guarantee the inviolability of the human being's right to life, "[From] the moment of conception until death" (Note 16). Thomas Aquinas protects the right to life only partially, that is when the fetus is endowed with reason and thus possesses a soul. Prior to such ensoulment, he regarded the fetus not as a human being and it can be dispensed with willy nilly (Note 17).

Swartz asserts that from the moment of conception all human life must be respected, because of the adagium imago Dei (humankind as an effigy of God). He alleges that the prohibition on murder is established in Genesis on this effigy, "Whoever sheds man's blood, by man his blood shall be shed. For in the image of God He made man" (Note 18). The description of the unique value of humans in Psalm 8: 5 is striking, "Yet thou hast made him a little lower than God, And dost crown him with glory and majesty" (Note 19). Ratzinger stated in the Congregation for the Doctrine of the Faith, "God alone is the Lord of life from its beginning until its end: no one can, in any circumstances, claim for himself the right to destroy directly an innocent human being" (Note 20). And further, the Congregation stated, "From the time that the ovum is fertilized, a new life is begun which is neither that of the father nor of the mother; it is rather the life of a new human being with his own growth. It would never be made human if it were not human already" (Note 21). This is proof that a fetus is a human being and it must therefore be treated as a person (Note 22). Its integrity must be protected and nurture in the same way as would be the adult person. We also have the authority of the moral natural law which proposes that you do not unto other which you do not want them to do unto you. It means that you as an adult when you were a fetus and were not aborted, entails that you must to the same to your unborn baby.

Thomas Aquinas tended here to differ with the Church's position concerning the beginning of human life and abortion (Note 23).

\section{Adumbration of What the Research Entails}

It is generally accepted that each human person was once a fetus and that a healthy human fetus will become an adult human person, such as you and I (Note 24). This notion poses trouble for the metaphysical approach of Thomas Aquinas.

This dichotomy moves the research to engage in discourses about fetal development and full personhood.

The research questions as mentioned in the abstract are answered in this paper. The answers Thomas Aquinas furnished us is contingent upon the question, is the fetus a person. Thomas Aquinas managed to employ his metaphysics to reach an outcome that is tailored for it. But this journey was not only smooth, as we shall see from the renditions of writers congenial to him (such as embriologists) and his critics (ethicists). This research seeks to contend that Thomas Aquinas's sentiments on abortion are commensurable with the Choice on Termination of Pregnancy Act of South Africa or is rather adopted by the latter Act in disregard for the sanctity of life and human dignity. 
Although religion (and the law) do not possess definitive answers to ethical dilemmas, it consists of many rich traditions that have grappled with the meaning of life and as such it has something valuable to offer to the research and for contemporary discourse on the topic (Note 25). The Christian religion has been largely responsible for influencing the West toward a high valuation of individual life generally and of new-born life in particular (Note 26). Knowledge of the religious and philosophical influences in our backgrounds can help us describe how we came to our present convictions, attitudes and actions (Note 27).

Thomas Aquinas wants to be part of the solutions to the ethical dilemmas we face regarding abortion and the meaning of when human life begins. He certainly failed to pose an amicable solution and left instead problems of a bigger magnitude. He would not have followed the reasoning as envisaged in the research, has he not so profoundly been influenced by Aristotle. If Thomas Aquinas possessed knowledge of embryology, he would have had a whole different view about the beginning of life.

\section{Does Abortion Takes a Human Life?}

\subsection{Fetal Development}

Because of the congruity of these two schools of thought (The Pythagorean and Christianity), many people believed that abortion takes a human life and is therefore tantamount to murder. This mode of thought is, however, contingent upon the notion, that if human life begins at conception, then abortion always involves the taking of human life. This is, however, not the answer Thomas Aquinas wanted us to have. Thomas Aquinas's answers about abortion hinge upon the question, "at what point does human life begins?" In order to fit his metaphysical view, Thomas Aquinas is therefore forced to deny that human life begins at conception. He came to this conclusion by virtue of the influence Aristotle's biology has over him. This research will reveals Thomas Aquinas was influenced mainly by the writings of Aristotle and to some extent Plato (Note 28).

The discourse about the starting point of life engenders a look into fetal development. Under the exploration of fetal development, two opposite views need to be play off against each other, namely that human life start relatively early during pregnancy as opposed to the view that it starts relatively late (Note 29). These two points of view circle around two conceptions, "early fetus" and "late fetus." In order to understand these concepts, it is necessary to adumbrate on the genetics of early and late fetal development (Note 30).

Fertilisation occurs in one of the two fallopian tubes. In these tubes an ovum and a semen fuses and result in an oosperm, the zygote. The zygote divides up during the next four days and forms a blastocyst. Approximately six days after the blastocyst implants itself in the uterus, the fetus begins to exist. During the second week of pregnancy capacity for feeling or sensation has been formed by the fetus. During this stage (early stage of pregnancy) the fetus is not regarded as a human being although it comprises of human genetic material in its deoxyribonucleic acid (DNA) and ribonucleic acid (RNA) molecules (Note 31).

Late fetal development involves the further development of the feeling capacity (which has started during the early stage of development) and the functioning of a cerebral cortex (Note 32). It happens during the second month of pregnancy. With the development of a cerebral cortex the most important organs of the fetus is being formed and eventually a spine. Six weeks thereafter (after the second month of pregnancy) the fetus starts to reveal an undeveloped face and limbs. During this period the fetal brain shows features or characteristics similar as that of a mammal (Note 33).

The fetus is during this stage a miniature human and is to be regarded as a human being for all intends and purposes. From this stage of development everything grows in proportion until the fetus's actual birth (Note 34).

According to Thomas Aquinas, the fetus in the early stage of pregnancy does not possesses moral consciousness and is similar to a plant (Note 35). He therefore regards the fetus in the early stage of pregnancy not as a human being (as indicated earlier). His own words attests to this notion, "[The] fetus in the early stage of pregnancy is not a person" (Note 36).

Thomas Aquinas is adamant that human life does not begins at conception. This is evident from these biological observations. He avers that it is not abortion if the fetus is killed during the early stage of pregnancy (early fetus), because it lives the life of a plant (and an animal). It is only abortion if the fetus is killed after mid-pregnancy (late fetus), when intellect or rationality is bestowed upon it.

\subsection{Is the Fetus a Person?}

Thomas Aquinas approached the research question in terms of the point when the fetus becomes "formed" or recognizably human, or in terms of when a "person" came into being, that is, infused with a "soul" or "animated." 
Until the fetus has a human soul - it is not a human being. As mentioned earlier, to destroy a fetus (early fetus) is not to destroy a human being. Aquinas believed this fetus will go out of existence regardless of whether it is aborted. He alludes that you and I could not have been aborted in the first trimester, because you and I did not exist then. Idaho defines the first trimester as the first 13 weeks of pregnancy, whereas Illinois delineates it as twelve weeks from ovulation (Note 37). Other authors suggest that a human being exists from around the eight week, when the brain stem begins to trigger bodily motions (Note 38). The renditions of the above authors about the formed fetus or infusion of the soul are in the light of this research too premature. Aquinas does not delineate the period, but he believed infusion of the soul or animation happens around mid-gestation. Mid-gestation denotes a twenty or a twenty-something-week duration or stage. By this stage during pregnancy, Aquinas would have claimed that the fetus (late fetus) has the capacity in hand for rationality, in other words that it can be regarded as a potential human being. This is the point at which the fetus begins to move in the uterus. As mentioned this comes around the twentieth week of pregnancy. Aquinas believed the fetus becomes human at this moment, also known as quickening (Note 39). "To be a human animal requires [...] reasoning or thinking" (Note 40). If anything with a human soul does have the capacity for thought, it is regarded as a human being. In my personal opinion and spoken from a layman's perspective (and in opposition to the Church magesterium), I am skeptical that Thomas Aquinas was too hasty in assigning personhood status to an unborn fetus during mid-gestation. I would have pushed the beginnings of human life or infusion of the soul in the fetus to a date later in the pregnancy phase. Many philosophers are of the view that not even a new-born is a full-fledged person. On the strength of this statement, I find it hard to believe that the fetus in mid-gestation of pregnancy has the capacity to think. It is just implausible. But nevertheless, Thomas Aquinas's time frame about infusion is more reasonable and logical than other authors (he accords a longer time frame for the infusion of the soul or rationality on the fetus). It is submitted that Thomas Aquinas's view hinges rather upon movement by the fetus in the womb as its acceptance of intellect or rationality.

In view of these contentions, if we understand a person to be an individual who possess a degree of self-consciousness, then, the fetus (early fetus) does not qualify to be called a person. On the strength of these notions, it seems to be absurd to think that a few unformed cells could count as a human being.

These views have interesting implications for the modern debate, in that they show how traditional theological conceptions of the soul actually gives us reason to deny that early-term fetuses (prior to 12 weeks) are human beings. As mentioned Thomas Aquinas accords early fetuses' to be prior to mid-gestation or twentieth week of pregnancy. Thomas Aquinas' views have been adopted by the South African Choice of Termination of Pregnancy Act (Act 92 of 1996) and fixed at an earlier date, namely 12 weeks wherein the execution of abortion is made legal.

\subsection{Requirement of a Body}

The intellect needs a body as its instrument so as to enable it to function rationally. For the human (mind) to operate at all, it must be attached to the proper sort of body. Aquinas says that the intellective soul needed to be united to a body that could serve as an appropriate organ for sensory perception (Note 41).

Thomas Aquinas conceived of the soul as substantial form. A substantial form makes a thing exists as the sort of thing it is. A substantial form gives a thing its very identity, its very existence (Note 42). This notion must be read in conjunction with a human being. A human being must have the capacities for sensation, emotion, desire and memory. According to Thomas Aquinas, these capacities required the right sort of body (Note 43). He believed without such a body, God would not infuse the human soul. To be a human requires something more: reasoning or thinking. Anything with a human soul must have the capacity for thought (Note 44). Until that capacity is present, the rational soul cannot be infused.

In taking an opposite viewstand, for example, if we assume that a human soul can exist without an appropriately organized body, then why couldn't human souls exist without any body at all, before the moment of conception. Thomas Aquinas argued against the pre-existence of the human soul. According to him (Thomas Aquinas), Origin (185-253) held that human souls pre-existed their bodies and were forced into them as a form of punishment (Note 45). Augustine held a similar view as Origin and said our souls might have existed before their current earthly incarnation. "[I] do not know, Lord, where I came here form, into this dying life, as I call it, or living death" (Note 46). This seems similar to a verse in the Holy Bible where God says that He knew us before we were born. This tends to lend credibility to the viewpoint that we existed in some other form before taking the human form or before ensoulment took place by the fusion of the spermatozoa and the ovum.

Thomas Aquinas's chief argument against the soul's pre-existence rested on the claim that God would not create a human soul except as the form of a human body. In his Questiones Disputatio de Potentia, Thomas Aquinas 
reasoned as follows, the human soul is not naturally complete outside the body, and God does not create the human soul outside the body either (Note 47).

Before the rational soul is infused, the fetus has no mind with which to conceptualize. Once the rational soul is infused, Thomas Aquinas believed, it is only then that the newly human fetus begins to use its mind. The fetus receives enough sensory stimuli to set the intellect in motion (Note 48). It is around mid-gestation of pregnancy that a fetus begins to engage in cognitive activity. It is the point where the brain has sufficiently developed to support the operations of intellect (Note 49).

Whether a fetus is genuinely engaging in conceptual thought is a dubious matter, but Aquinas gave the fetus the benefit of the doubt, pushing the beginnings of human life as far back as he can (he accords $20^{\text {th }}$ week of pregnancy, whereas the Choice of Termination of Pregnancy Act stated a period prior to 12 weeks) while remaining consistent with his broader theory of the soul, which requires a body.

\section{Nothing Is Ever First a Fetus and Later a Person}

\subsection{Thomas Aquinas's Metaphysics on Generatio et Corruptio}

The contentions that nothing is ever first a fetus and later a person poses or faces serious philosophical challenges.

Thomas Aquinas has distinguished (his distinction between early and late fetus) between an actual human and a potential human. On this analysis, he casted it illegitimate to speak of the human body even before the rational soul has been infused (early fetus). Aquinas warned though, the body's being potentially human does not entailed its being actually human (Note 50). When we say that things are potentially such and such, we mean that they are not such and such, but that they could be at a later point. Could this be applied to a human fetus? Aquinas asserted that there were many things that are potentially human beings. Each of the cells of a human body is potentially a human being, inasmuch as each one might be developed into a full-fledged human being (Note 51).

But Thomas Aquinas would say that my early life as a fetus is not really my life, insofar as I, the human being, did not exist then. He means a different, non-human substance, existed then (Note 52).

Thomas Aquinas infused changes into the development of the fetus. His thinking was in line with the general view of generatio et corruptio (of Aristotle). He alluded to the fact that where some complex substance is generated, its development runs through a series of intermediary substances, each with its own substantial form. He mentioned: "It is clear in the generation of composite things, such as animals, that in between the principle of generation (the semen) and the ultimate form of the complete animal, there are many intermediary generations" (Note 53). It can therefore be inferred that the same is true for corruption: "[It] is not that, once the soul is corrupted, the body of the animal immediately dissolves into its elements: instead, this happens through many intermediary corruptions" (Note 54). Aquinas meant that if we suppose that the soul is united to the body as its form, then it seems entirely impossible for several, different souls to be within one body (Note 55). Only two substantial forms are at interplay with each other: the one that is given up and the one that is taken on (Note 56).

Thomas Aquinas asserted that a change in species entailed a change in identity. The prior substance must be corrupted and a new one generated (Note 57). Human generation fits this complex model: "First the seed appears, then the blood, and so on until the form of the human" (Note 58). Aquinas emphasized, as mentioned elsewhere in the research, that the human being begins when the human mind comes into the scene.

On the basis of this metaphysical conception, Thomas Aquinas avered that the fetus first has a nutritive soul, then a sensory soul, and finally a rational soul (Note 59). He rejected the notion that there are multiple souls. He wrote, "[When] the rational soul is infused, the prior soul gives way; this must be the case, [Aquinas believes], because in all cases 'one thing has just one substantial form" (Note 60). He thus rejected the idea of multiple souls, because the prior sensory form is cast off (abiecta) when the rational soul is infused (Note 61). Aquinas showed sympathy with the ordinary reader when he says, "[Because] a [n] [fetus] first has a nutritive soul, then a sensory soul, and finally (seemingly on top of all) a rational soul, it looks as if a human being should have three different souls" (Note 62). The sensory soul comes later and the rational soul later still. Each time a new soul develops, a new substance comes into existence. He writes: "The vegetative soul comes first, when the [fetus] lives the life of a plant. Then it is corrupted, and a more complete soul follows, at once both nutritive and sensory, and then the [fetus] lives the life of an animal. But once this is corrupted, the rational soul follows, introduced from without" (Note 63). Aquinas concluded by saying that there are no multiple souls (Note 64). He reasserted that the human being has only one soul, a rational soul or a rational soul is a human being's only substantial form (Note 65). 
Thomas Aquinas meant before the final stage, we have something that is alive, and something that, in virtue of its potential, merits the adjective "human." He reassured us that only at this last stage (late fetus) do we have a human being (Note 66).

Thomas Aquinas ensured us that a generation involves constant discontinuity, as is evident in this research. He asserted that the human being that now exists never was a fetus. According to Thomas Aquinas, to destroy a fetus (early fetus) is not to destroy a human being, nor is it even to destroy some entity that will become a human being. He argued that the process of generation ensures that the fetus (early fetus) will go out of existence regardless of whether it is aborted. He alluded that you and I could not have been aborted in the first trimester, because you and I did not exist then. Thomas Aquinas believed what exist then, existed only for a transient moment (Note 67).

Thomas Aquinas stated when a fetus becomes a human being, the fetus (early fetus) is corrupted. Or rather the fetus goes out of existence in the same way that a caterpillar goes out of existence when it becomes a butterfly (Note 68).

\section{Modern Day Proponents and Critics of Thomas Aquinas's Metaphysical Renditions: A Practical Application}

Ethicists, on the one hand (and in line with the Church's stand), agree that a human fetus (irrespective of early or late fetus) is at least a potential person. It might later be a person: "It is obviously true that the normal fetus is at least a potential person: it is an entity which will [...] develop into something incontestably a person [...]" (Note 69). From this angle, it seems that they assume that it is possible for something to be an unthinking fetus at one time and a person later on. Embryologists would argue, on the other hand, that a fetus is not even a potential person (Note 70).

As established in Thomas Aquinas's thought, what distinguish people from non-people are the concepts of rationality and self-consciousness (Note 71). It goes along the line of argument that a fetus (early fetus) does not come to be a person as mentioned under the generatio et corruptio principle.

After envisaging the tenor of this research, the question one can asks is what happens to the original fetus then? Two possibilities seem to surface, which are concomitant to Thomas Aquinas's generatio et corruptio doctrine. One possibility is that the fetus ceases to exist and is replaced by a person. The other, is that the fetus continues to exist, but never comes to be a person. These two possibilities have the same effect in Thomas Aquinas's metaphysics: He is simply stating that human life does not begin well after conception (mid-gestation). According to the first possibility, it is impossible for a human fetus to come to be a normal, adult human being. The fetus ceases to exist as soon as its nervous system has developed enough to make thought possible (Note 72). The second option is that a human fetus does survive the normal development of its nervous system, but despite that development, it never comes to be a person. No human fetus ever comes to be one of us. "You, the person, now share your space and your matter with a human animal, and it is the animal, not you, that started out as a fetus [...] The animal is numerically different from you because it began to exist before you did, and because it has different dispositional properties from yours: you could not survive without psychological continuity, but the animal accompanying you manifestly can, or at least it could, and did, at one time" (Note 73)

On the strength of these views, it seems absurd in treating a newly formed fetus as a human being (Note 74). A fertilized cell counts as human, inasmuch as it contains a human genetic code, but it is not yet a person and so does not yet have the moral status of a full-fledged human person (Note 75). This runs along the line that an unformed mass of cells cannot count as a human being (Note 76).

\section{Practical Implications}

Ethicists and pro-life proponents would argue that the failure by Thomas Aquinas of affording to a fetus (in the early stage) the status of "person" might serves as an affront to its right to life and its dignity as enshrined in section 11 of the Constitution of the Republic of South Africa, Act 108 of 1996 and the Church's sentiment on the sanctity of life. The Constitution would evoke section 11, which reads: "Everyone has the right to life," and forwarding sentiments uttered by the Constitutional Court whereby the rights to life and dignity were held as the 'most important of all human rights." According to Judge Langa (whose sentiments are conjunction with the Church's regarding the sanctity of life) the Constitutional Court (in $S v$ Makwanyane) (Note 77), held that the state should be a role model of our society and must demonstrate society's own regard for human life and dignity by refusing to destroy life. If we follow the tenor of Thomas Aquinas's thought, we can put ourselves into his shoes, and argue that notwithstanding the sentiments in the Makwanyane-case, South Africa, for example, has turned a blind eye to this noble legislation, by promulgating or accepting the Choice on Termination of 
Pregnancy Act (Act 92 of 1996) in its legislative framework. We are therefore faced with a dichotomy - the affording of the right to life and dignity as enshrined in the Constitution on the one hand and the Choice on Termination of Pregnancy Act on the other hand which wants to take life away. It serves as a paragon for the notion that life is given with the one hand, just or only to be taken away again with the other hand.

This indecision gives leverage for individual freedom and physical integrity, which culminates in laws that favour freedom of choice. One such law is the Choice on Termination of Pregnancy Act of South Africa.

Other well known laws are the United States Supreme Court decisions in Roe v Wade (Note 78) (successful privacy challenge of a law criminalizing abortion); Cruzan v Director Missouri Dept of Health (Note 79) (unsuccessful application to terminate feeding of patient in vegetative state, and Washington $v$ Gluksberg (Note 80) (no constitutional basis for a right to assisted suicide). In South Africa, the Choice on Termination of Pregnancy Act permits abortion on request by a woman during the first 12 weeks of her pregnancy, for medical and social reasons in the $13^{\text {th }}$ to the $20^{\text {th }}$ week of pregnancy and after the $20^{\text {th }}$ week, to save the life of the woman or to prevent the fetus being born malformed or injured. In Christian Lawyers' Association of South Africa v Minister of Health (Note 81) the Act was challenged in the High Court on the basis that it permitted the termination of human life. The High Court rejected the challenge on the basis that the word "everyone" used in section 11 to describe the bearers of the right to life, does not include a fetus. This Court's decision is echoing what Thomas Aquinas has said.

\section{Conclusion}

Thomas Aquinas contention that an early fetus does not count as a human being until it possess a soul, moves him to assert that early abortions is permissible and do not count as murder. This notion is contingent upon the point at which human life begins. It is revealed in this research that human life begins well after conception. Thomas Aquinas said it is during mid-gestation, in other words around the twentieth week of pregnancy. It is only then that we have a human being. He afforded the fetus (late fetus) at that stage to be in possession of intellect. This notion engendered that Thomas Aquinas collided with the Church on issues such as sanctity of life.

Thomas Aquinas's treatment of the fetus, has however implicitly been adopted by the modern-day South African Choice of Termination of Pregnancy Act. There seems therefore a tendency to conflate interest in medieval philosophy, especially in the work of Thomas Aquinas. The research stresses that the debate in which Thomas Aquinas engaged with the Church is not just over whether abortion takes a human life, but also over questions about the right to life, the right to dignity, and woman's control over their own body, the proper role of government, constitutional interpretation and the value of life. In this tangled nest of questions, this research echoes there must be found room for common ground: the sanctity and dignity of (human) life.

\section{References}

Augustine. Confessiones.

Aristotle. Met.

Aristotle. Phys. III.

Aristotle. De Gen.

Boethius. Contra Eutychen.

Choice on Termination of Pregnancy Act. Act 92 of 1996.

Christian Lawyers Association of South Africa v Minister of Health. 1998 (4) SA 1113 (T).

Congregation of the Doctrine of the Faith. St Paul Publicatione Africa 1987.

Constitution of the Republic of South Africa. Act 108 of 1996.

Cruzan v Director Missouri Dept of Health. 497 US 261 (1990).

Currie, I., \& De Waal, J. (2005). The Bill of Rights Handbook (5th ed.). Juta Cape Town.

Dombrowski, D. A., \& Deltete, R. (2000). A Brief, Liberal, Catholic Defense of Abortion. Illinois Press Urbana.

George, B. J. (1986). State Legislatures versus the Supreme Court: Abortion Legislation in the 1980s. In J. D. Butler, \& D. F. Walbert, Abortion, Medicine, and the Law (3rd ed.). Facts on File Publications New York.

Hebrew-Greek Key Study Bible Red Letter Edition. (1960). New American Standard. AMG Publishers Chattanooga USA. 
John, P. II. (1995). Evangelium Vitae: On the Value and Inviolability of Human Life. Washington DC. Retrieved from http://www.nccbuscc.org/profile/tdocs

Kenny, A. (1993). Aquinas on Mind. Routledge London.

Olsen, E. T. (1997). The Human Animal. Personal Identity without Psychology. Oxford University Press Oxford.

Packwood, B. (1986). The Rise and Fall of the Right-to-Life Movement in Congress. Response to the Roe Decision 1973-1983. In J. D. Butler, \& D. F. Walbert, Abortion, Medicine, and the Law (3rd ed.). Facts on File Publications New York.

Pasnau, R. (2002). Thomas Aquinas on Human Nature. A Philosophical Study of Summa Theologiae 1a 75-89. Cambridge University Press Cambridge.

Pinchin v Santam Insurance Co. Ltd. 1963 (2) SA 254 (W).

Roe $v$ Wade. 410 US 113 (1973).

Sv Makwanyane. 1995 (4) SA 391 (CC).

Schneiderman, L. J. (1997). Foreword. In J. W. Walters, What is a Person? An Ethical Exploration. University of Illinois Press Urbana.

Swartz, N. P. (2007). Thomas Aquinas oor die Aborsie-Debat en die Kerk Magesterium. Tydskrif vir Regswetenskap, 32(2), 132-146.

Swartz, N. P. (2009). Rosmini on Individual Rights: The Soul (Reason) as Forerunner of Individual Rights in Human Society. Journal of Politics and Law, 2(3), 100-106.

Thomas Aquinas. Summa Theologiae.

Thomas Aquinas. In Met.

Thomas Aquinas. De Principiis.

Thomas Aquinas. In Quattuor libros Sententiarum.

Thomas Aquinas. Summa Contra Gentiles.

Thomas Aquinas. In duodecim libros Metaphysicorum.

Thomas Aquinas. In librum primum De Generatione et corruption expositio.

Thomas Aquinas. Quaestiones disputatae de potentia.

Thomas Aquinas. Quaestiones disputatae de anima.

Thomas Aquinas. Quaestiones quodlibetalis.

Washington v Gluksberg. 521 US 702 (1997).

\section{Notes}

Note 1. Roe v Wade 410 U.S. 113; 93 S.Ct. 705; 35 L.Ed. 2d 147; 1973 U.S. Lexis 159. End Footnote 2.

Note 2. Roe $v$ Wade End Footnote 130.

Note 3. Roe v Wade End Footnote 130.

Note 4. Roe $v$ Wade End Footnote 130.

Note 5. Roe $v$ Wade End Footnote 2. The Oath originated in a group representing only a small segment of Greek opinion and that it was not accepted by all ancient physicians. Medical writings down to Galen (A.D. 130-200) "give evidence of the violation of almost every one of its injunctions." With the end of antiquity a change took place. The Oath after becoming popular became the nucleus of all medical ethics and was applied as the embodiment of truth.

Note 6. Roe $v$ Wade End Footnote 2.

Note 7. Roe $v$ Wade End Footnote 2.

Note 8. Roe $v$ Wade End Footnote 2.

Note 9. Senator Packwood B The Rise and Fall of the Right-To-Life Movement in Congress: Response to the Roe Decision 1973-1983. In Butler \& Walbert Abortion, Medicine, and the Law (New York 1964) 4. 
Note 10. Swartz NP "Thomas Aquinas oor die Aborsie-Debat en die Kerk Magesterium" 2007 Tydskrif vir Regswetenskap 132.

Note 11. John Paul II Evangelium Vitae: On the Value and Inviolability of Human ch. 3, sec 60. Available at http:///www.nccbuscc.org/profile/tdocs. In Pasnau R Thomas Aquinas on Human Nature: A Philosophical Study of Summa Theologiae la 75-89 (2002) 110.

Note 12. John Paul II Evangelium Vitae (1995) ch. 1, sec 13.

Note 13. Swartz NP "Thomas Aquinas oor die Aborsie-Debat en die Kerk Magesterium" (2007) 132.

Note 14. Swartz NP "Thomas Aquinas oor die Aborsie-Debat en die Kerk Magesterium" (2007) 145.

Note 15. Swartz NP "Thomas Aquinas oor die Aborsie-Debat en die Kerk Magesterium" (2007) 138.

Note 16. Congregation of the Doctrine of the Faith (1987) 10.

Note 17. Swartz NP “Thomas Aquinas oor die Aborsie-Debat en die Kerk Magesterium” (2007) 140.

Note 18. The Hebrew-Greek. Key Study Bible. New American Standard (The Lockman Foundation AMG Publishers USA 1960) Genesis 9: 6.

Note 19. New American Standard (1960) Psalm 8: 5.

Note 20. Congregation for the Doctrine of the Faith (1987) 11.

Note 21. Congregation of the Doctrine of the Faith (1987) 13.

Note 22. Swartz NP "Rosmini on Individual Rights: The Soul (Reason) as Forerunner of Individual Rights in Human Society" 2009 Journal of Politics and Law Canadian Center of Science and Education 102. With regard to the issue of whether a fetus can be treated as a human being, I have embarked upon the opposing sentiments of Thomas Aquinas and Antonio Rosmini vis-à-vis the nasciturus fiction in the South African law. Rosmini desires to ascribe legal subjectivity (legal personality) to the fetus, but is prevented from doing so by the South African common law, since a legal subject in the technical sense refers to someone that is endowed with rights and obligations. This means that, despite the fact that the fetus is an intellectual and rational being and thus has a soul, it still does not have legal subjectivity 9legal personality). In terms of the South African common law, the legal subjectivity of a natural person only begins at birth. An unborn child (fetus) is, for the purposes of the law, not a legal subject, since it has not yet been born. Rosmini's dilemma is, however, solved by a legal institution, the nasciturus fiction, of South African law. According to Judge Hiemstra, the nasciturus fiction in the case of Pinchin v Santam Insurance Co. Ltd 1963 (2) SA 254 (W) involves that the fetus can be viewed as a living being (born) [regardless of the stage of pregnancy], if it is in the fetus' interest or to its advantage. This finding by the judge implies that Thomas Aquinas' distinction between early and late pregnancy can be dispensed with, and that in both stages of pregnancy (early and late) the fetus should be endowed with legal subjectivity. The thought can be rounded off as follows: When the fetus is born alive, it will be to his or her advantage. According to this, the fetus not only benefits by virtue of the nasciturus fiction, but, just like every person, is also entitled to the protection of his or her individual right, namely his or her right to life (as guaranteed by section 11 of the South African Constitution 108 of 1996. Owing to the nasciturus fiction, the fetus will have subjective rights, provided it is to his or her advantage. But what if this provision is not met? Does this mean that the fetus' subjective right is denied? If that is the case, Thomas Aquinas' argument that the fetus is a plant (anima vegetativa) or animal (anima sensitiva) in the early stage of pregnancy, would be correct. The result thereof is that the fetus is not a legal subject, and therefore does not have individual rights. His or her individual rights (the right to life) can thus, according to Thomas Aquinas and the South African common law, be encroached upon. On these grounds, Rosmini can argue that the prescriptions of the nasciturus fiction should be expanded - not only to the point where it is entitled to an advantage, but also if there is no material benefit for him or her.

Note 23. Pasnau R Thomas Aquinas on Human Nature (2002) 110. The Church, has officially, never taken a position on the philosophical question of when human life begins. In an encyclical, the late John Paul II noted that the Church has not "expressly committed itself" on the moment when human life begins. But the Church's rhetoric leaves little room for doubt. In that same encyclical, the Pope writes that abortion "destroys the life of a human being" and "directly violates the divine commandment "You shall not kill." That expresses the Church's position with regard to abortion.

Note 24. Olson ET The Human Animal. Personal Identity without Psychology (1997) 73.

Note 25. Schneiderman LJ Foreword. In Walters JW What is a Person. An Ethical Exploration (1997) ix.

Note 26. Walters JW What is a Person (1997) 8. 
Note 27. Walters JW What is a Person (1997) 14.

Note 28. Swartz N "Thomas Aquinas oor die aborisie-debat en die Kerk magesterium" 2007 Tydskrif vir Regswetenskap 135.

Note 29. Thomas Aquinas Summa Theologiae 1a, q. 76, a. 3.

Note 30. Swartz N "Thomas Aquinas oor die aborsie-debat en die Kerk magesterium" 2007 Tydskrif vir Regswetenskap 133.

Note 31. Swartz N "Thomas Aquinas oor die aborsie-debat an die Kerk magesterium" 2007 Tydskrif vir Regswetenskap 133.

Note 32. Dombrowski DA \& Deltete R A Brief, Liberal, Catholic Defense of Abortion (2000) 11

Note 33. Thomas Aquinas Summa Theologiae 1a, q. 76, a. 3.

Note 34. Thomas Aquinas Quaestiones disputatae de potential 3III ad ii.

Note 35. Thomas Aquinas Summa Theologiae 1a, q. 76, a. 3.

Note 36. Thomas Aquinas Summa Contra Gentiles II.89.1752.

Note 37. George State Legislatures Versus The Supreme Court: Abortion Legislation in the 1980's. In Butler JD \& Walbert DF Abortion, Medicine, and the Law (1986) 32-33.

Note 38. Pasnau R Thomas Aquinas on Human Nature (2002) 118.

Note 39. Pasnau (2002) 112.

Note 40. Pasnau (2002) 115.

Note 41. Thomas Aquinas Summa Theologiae 1a, q. 76, a.5.

Note 42. Pasnau R Thomas Aquinas on Human Nature (2002) 114.

Note 43. Pasnau R Thomas Aquinas on Human Nature (2002) 114.

Note 44. Pasnau R Thomas Aquinas on Human Nature (2002) 115.

Note 45. Thomas Aquinas Summa Contra Gentiles II.83-84.

Note 46. Augustine Confessions I.vi.7.

Note 47. Thomas Aquinas Quaestiones disputatae de potentia 3.10c.

Note 48. Pasnau R Thomas Aquinas on Human Nature (2002) 118.

Note 49. Pasnau R Thomas Aquinas on Human Nature (2002) 119.

Note 50. Pasnau R Thomas Aquinas on Human Nature (2002) 121.

Note 51. Pasnau R Thomas Aquinas on Human Nature (2002) 121.

Note 52. Pasnau R Thomas Aquinas on Human Nature (2002) 121.

Note 53. Thomas Aquinas In librum primum De generatione et corruptione expositio I.8.60.

Note 54. Thomas Aquinas In librum primum De generatione et corruptione expsotio i.8.60.

Note 55. Thomas Aquinas Summa Theologiae, 1a, q. 76, a. 1.

Note 56. Thomas Aquinas Quaestiones disputatae de potentia 3.9 ad 9.

Note 57. Pasnau R Thomas Aquinas on Human Nature (2002) 123.

Note 58. Thomas Aquinas Quaestiones disputatae de potentia 3.9 ad 9.

Note 59. Thomas Aquinas Summa Theologiae, 1a, q. 76, a. 3 obj 3.

Note 60. Thomas Aquinas Summa Theologiae, 1a, q. 76, a. 4.

Note 61. Thomas Aquinas Summa Theologiae, 1a, q. 76, a. 3 ad 3.

Note 62. Thomas Aquinas Quaestiones disputatae de anima (Leonine vol. 24, 1).

Note 63. Thomas Aquinas Summa Contra Gentiles II.89.1745.

Note 64. Thomas Aquinas Summa Theologiae, 1a, q. 76, a. 3 ad 3.

Note 65. Pasnau R Thomas Aquinas on Human Nature (2002) 127. 
Note 66. Pasnau R Thomas Aquinas on Human Nature (2002) 122.

Note 67. Pasnau R Thomas Aquinas on Human Nature (2002) 124.

Note 68. Pasnau R Thomas Aquinas on Human Nature (2002) 125.

Note 69. Olson ET The Human Animal (1997) 77.

Note 70. Olson ET The Human Animal (1997) 77.

Note 71. Olson ET The Human Animal (1997) 79.

Note 72. Olson ET The Human Animal (1997) 79.

Note 73. Olson ET The Human Animal (1997) 80.

Note 74. Pasnau R Thomas Aquinas on Human Nature (2002) 106. The Supreme Court in Roe v Wade concluded that abortion does not take a human life. If the Court had taken the possibility that human life begins at conception, it never could have reasoned in the way it did.

Note 75. Pasnau R Thomas Aquinas on Human Nature (2002) 107.

Note 76. Pasnau R Thomas Aquinas on Human Nature (2002) 108.

Niote 77. 1995 (3) SA 391 (CC).

Note 78. 410 US 113 (1973).

Note 79. 497 US 261 (1990).

Note 80. 521 US 702 (1997).

Note 81.1998 (4) SA 1113 (T).

\section{Copyrights}

Copyright for this article is retained by the author(s), with first publication rights granted to the journal.

This is an open-access article distributed under the terms and conditions of the Creative Commons Attribution license (http://creativecommons.org/licenses/by/3.0/). 